case when it was wholly in the air, because, to be of any use then, the strokes would have to be so rapid as to be scarcely countable, as is the case with ccrtain sea fowl (notably auks) which use their wings (with a comparativcly slow stroke) whilst swimming under water, but when flying move them so rapidly that the strokes can either be counted with difficulty or not at all. On watching flying-fish whilst in the air, I noticed a flickering of the fins, indicating what $I$ believe to have been rapid motion.

As Mi. Mitchell's olsservations, on which he chiefly relies, were made when looking down from the high bows of a steamer, the "waving from side to side" of the tail of the fish, being a lateral motion, was clearly seen, whilst the movements of the side fins would be less easily discernible.

Finally, could the impetus acquired by the fish, when spring. ing from the water, earry it through the air " 50 or 100 yards" (Mr. Mitchell's estimate) without the aid of any additional propelling force during its fight? If so, the initial velocity must have been very great.

4, Addison Gardens, W., November 27

\section{The "Jeannette" Drift}

IN NATURE of November $20(p, 66)$ you give an account of the finding of some relics of the feannelte, which have been picked up on an ice-floe at Julianhaab, in lat. $6 \mathrm{I}^{\circ} \mathrm{N}$., long. $46^{\circ} \mathrm{W}$., near the south point of Greenland, and which must have drifted from the $\mathrm{New}$ Siberian Islands in lat. $75^{\circ} \mathrm{N}$., long. $155^{\circ} \mathrm{E}$, where the fannelle was squashed three years ago. 'This I consider a most important find with regard to Arctic navigation and discovery. The question ariscs, How did the ice-floe get to Julinnhaab? I propose the following solution. The Siberian Islands bear ncarly due north from Julianhaab, and in a straight line up Davis's Strait, Baffin's Bay, Smith's Sound, Lincoln Sea, \&c., and across at a distance of about 250 knots from the Pole. I think it most probable that the floe may have drifted through "the unknown," or what Osborn calls " the land of the white bear," the large unexplored arca to the west of Bariss's Land, and have got into Baffin's liay through one of the sounds on its west coast---either by Jones's Sound, where the tide runs eastward at the rate of two knots an hour ("Ingleficld," P. 77), or by Banks's Strait and Lancaster Sound.

We know that the icebergs come durin Baffin's Bay and Davis's Strait into the Atlantic, and the floe has had fair success in navigating through a distance of 2700 knots to reach Julianhaab in three years.

I cannot for a moment suppose that this ice-floe has come from the Siberian Tslands, win Francis Joseph Land, Spitzbergen, Iceland, to Grcenland, a distance of 3600 knots, for that course would have been directly agrainst the Gulf Stream, in which no floe could last three years, even if it were 26 fect thick, as Inglefield found them in Jones's Sound, or 40 fect thick, as MeClure found them in Banks's Strait. McClure found the current west of Point Barrow going 2 knots per hour to the south, evidently making for Behring's Strait, while of the northwest point of Banks's Land the drift was north-east $\bar{I}$ knot an hour, evidently going towards I ancaster Sound.

I therefore conclude that the feannette relics could not have come westward, they must have come eastward, and this proves that there is a course open which is unknown to us.

I would suggest that a number of very strong buoys, capable of resisting ice-pressure, should be set adrift on ice-floes on various parts of the Sibcrian coast, cach numbered indelibly, so that when recovered it could be ascertained whence they started, and their course might possibly be ascertained from the listimo, who may have seen them, or by other means. 'This experiment is wortl a trial.

Ferndene, Normber 30

R. S. NEWALL

\section{A Meteor Visible in the Daytime}

AT Waterpark, just below Waterford City, about 4 p.m. on October 15 , my attention was attracted by a flash of increased light. Looking up, I saw in the south-south-west, about half way between the horizon and the zenith, a bright meteor slowly sailing nearly due west, its apparent size about half that of the full moon, intensely white in colour at the centre, passing into blue at the circumference. It described a low arc, and was in sight for several seconds, learing a trail of indigo blae with lighter luminous edges. The meteor disappeared behind some clouds which concealed the sun at a considerable altitude above the horizon.

November 27

JAMES GRAVES

\section{Noon-Glow}

Wirme waiting at the telescope shortly before noon this date to note place of sun-spots at meridian passage, masses of cloud formed suddenly in a clear sky overhead, and drifting slowly due south, obscured a peculiarly brilliant sun. No sooner had direct light been intercepted than the upper air above cloud and sun's place appeared filled with the latterly common white glare (as of attenuated peat-smoke highly illuminated), which soon became suffused with the now familiar rose-tint, apprarent also between the clouds and on south-south-west horizon, but not beneath the sun on meridian. The sun's apparent meridian altitude being $16^{\circ}$, the superior limit in altitude of rose-tint was $39^{\circ}$; the colouring being monotone throughout, and not to be confounded with that of halos. Fearing ocular deception, as often happens from fatigue of eyesight, $I$ asked an intelligent companion to verify observation, more especially as the diffused white glare at first slightly masked the tinting as compared with that of other "glows." It seems, however, plain that the terns "fore-glow" and "after-glow" no more cover the entire field than the Krakatoan dust.

Kingstown, November 24

D. J. ROWAN

\section{Rosy Glow about the Moon}

AFTER watching for some time this evening a lovely twilight in the west, which though bright and luminous was not remarkable for strong colour, I turned toward the south-east, when the moon, now well up, was shining through detached fleecy clouds, and was surprised to see about her a rosy-coloured glow, very like that so often seen about the sun; the nearer clouds, though very high, telling as a cold almost greenish grey upon it. This glow, of course, was much lower in tone than that about the sun, but both in character and extent just like it, and quite distinct, and broader than those prismatic hues often seen about the moon, and called by sailors "cock's eyes" or peacock's. eyes. This was at $4.45 \mathrm{p} . \mathrm{m}$. , and as the twilight faded the glow clisappeared, from which I infer that it was caused by vapour lying high enough in the south-east to catch some of the very last rays of the sun, but too far east to give a glow in the west.

I see that a correspondent of the Standard telegraphed that on the evening of the 25 th " a sunset equal in splendour to those of last autumn was seen over the Yorkshire wolds. The predominating hue was a rich crimson." The weather here was cloudy that evening, but between narrow opening; in the clouds the sky was the colour of rich painted glass of a ruby-red tint about $4.30 \mathrm{p} . \mathrm{m}$.

6, Moira Place, Southampton, November 28

\section{Wild Fowl Decoy}

MAY I ask if any of your readers who are interested in wildfowl decoys will send me the names and positions of any past and present ones they may happen to know or have heard of. I am endeavouring to save the history of decoys from oblivion, and though I have many hundred letters, maps, and sketches connected with this interesting subject, still I may have a great deal of information yel to obtain. I think the subject deserves a standard work, or I would not trouble you.

\section{RAIPH PAYNE GaLLWEY}

\section{Cowling Hall, Bedale, November 24}

\section{Prehistoric Man}

DURING October last, the sanitary authoritics of Gloucester City had occasion to make some excavations in the timber-yard of Messrs. Booth and Co., and in the Bristol Road adjoining this yard, for the purpose of laying down a new sewer. In the course of this operation the workmen disinterred, from a bed of plastic clay, three human skeletons, occupying a position which appears to suggest that the remains in question are probably those of prehistoric man.

Arriving accidentally on the spot some two or three days after the actual find, I lcarned, to my great regret, that the skulls, two of which had passed through my friend Mr. Wm. Booth's 